ILLUSTRATIONS AND MUSICAL EXAMPLES

\title{
FIGURES
}

1. Louis Marks's depiction of Velluti 26

2. "Caro suono lusinghier" 32

3. A view of Bichat's "little brains" 47

4. Paolo Mascagni, Tavole figurate di alcune parti organiche del corpo umano 52

5. A neuromuscular view of the insulated hand 53

6. Chopin's Étude op. 25, no. 3, coda, with fingerings at m. 6960

7. Chopin's Étude op. 25, no. 3, mm. 1-16 61

8. A phantom hand sounds the melody in Fantaisie pour le piano 96

9. The operatic "slow movement" of Kalkbrenner's Effusio musica 108

10. Jacques-Marie Delpech's apparatus for a straight spine and erect head 112

11. The problematic leg-arm homology 116

12. Young and Delcambre's type-composing machine 120

13. Rosenberg's composing machine 121

14. Manuel García fils searches for voice in Traité complet de l'art du chant 127

15. Francesco Bennati, Recherches sur le mécanisme de la voix humaine 128

16. Johann Nepomuk Czermák, Du laryngoscope et de son emploi en physiologie et en médecine 129

17. "Do" and "Re" as imagined in Gesualdo Lanza, The Elements of Singing 131

18. Édouard Fourniés view of glottis configurations 132 
19. Arnold disappears into the higher "Ah! Mathilde" in the Tell-Arnold duo from act $1 \quad 144$

20. Antoine-Jean Weber's lithograph after Charles-Guillaume Steuben's Le Serment des troi suisses 146

21. Jules Rigo's lithograph of Célestin Deshay[e]s, Guillaume Tell (2me Acte) 147

22. Jaëll-Liszt's Au bord d'une source 166

23. The opening of Harmonies poétiques et religieuses 169

\section{MUSICAL EXAMPLES}

1. Chopin's Étude op. 25, no. 3, the "A section" from m. 2963

2. Double cadenza preparing for the tempo di mezzo in Semiramide's "Ebben a te: ferisci" 75

3. The keyboard part of Moscheles, Gems à la Malibran 77

4. The trio "Ses jours qu'ils ont osé proscrire" with emotive tremoli and portamenti 142 